\title{
Regioselective hydrostannation of activated alkynes catalyzed by in situ generated copper hydride
}

\author{
Ru Miao, Shuoliang Li and Pauline Chiu* \\ Department of Chemistry and Open Laboratory of Chemical Biology of the Institute of Molecular Technology for Drug \\ Discovery and Synthesis, The University of Hong Kong, Pokfulam Road, Hong Kong, PR China
}

Received 4 January 2007; revised 25 April 2007; accepted 26 April 2007

Abstract - The hydrostannation of activated alkynes proceed in good yields and high regioselectivities catalyzed by $\mathrm{CuCl}$, in the presence of potassium tert-butoxide, triphenylphosphine, and tributylstannane, by generating copper hydride in situ. (C) 2007 Published by Elsevier Ltd.

\section{Introduction}

The Stille coupling is one of the most extensively utilized palladium-catalyzed carbon-carbon bond forming reactions, and numerous examples of its application in the syntheses of natural products are found. ${ }^{1}$ The application of the Stille vinylation reaction is dependent on the availability of vinylstannanes as precursors. Hydrostannation of alkynes is presently the most common way to gain access to vinylstannanes, with palladium complexes being the dominant catalyst for this reaction.

In this connection, we had previously reported on the use of copper as an alternative transition metal catalyst for hydrostannation in the form of hydrido(triphenylphosphine)copper(I) hydride hexamer, $\left[\left(\mathrm{Ph}_{3} \mathrm{P}\right) \mathrm{CuH}\right]_{6}(\mathbf{1}),{ }^{2}$ known popularly as Stryker's reagent. ${ }^{3,4}$ The hydrostannation appears to be initiated by the copper hydride undergoing hydrocupration with an activated alkyne substrate (Scheme 1). Transmetallation of the vinylcopper with tin produces the vinylstannane.<smiles>[R]C#CC(=O)OCC#CC(=O)OC</smiles>
$\mathrm{H} \cdot \mathrm{CuPPh}_{3}$

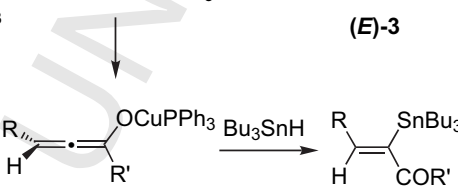

(Z)-3

Scheme 1. Hydrostannation catalyzed by $\mathbf{1}$.

Keywords: Hydrostannation; Reductions; Stannanes; Catalysis; Regioselectivity.

* Corresponding author. Tel.: +852 2859 8949; fax: +852 2857 1586; e-mail: pchiu@hku.hk
The overall reduction delivers hydride at the electrophilic $\beta$-position, resulting in only $\alpha$-stannylated vinylstannanes with comparable or superior regioselectivity than that obtained in palladium-catalyzed hydrostannations. ${ }^{5}$ This improved selectivity is important and has significant practical advantages, since isomeric vinylstannanes are often hard to separate chromatographically and succumbs to decomposition over time on silica gel.

Although this hydrostannation is more regioselective and economical than palladium for hydrostannation of activated alkynes, it uses discreet copper hydride $\mathbf{1}$ as catalyst, which needs to be purchased or synthesized in the laboratory. ${ }^{6}$ Thus an alternative protocol using a more common and convenient source of copper for hydrostannation, which still achieves high regioselectivity would be practical and desirable.

\section{Results and discussion}

Recently we found that copper(I) chloride, with potassium tert-butoxide and triphenylphosphine, all of which can be weighed in open air without the aid of a dry box, ${ }^{7}$ directly promotes hydrostannation in the presence of tributylstannane, thus obviating the need to separately prepare, isolate, and purify $\mathbf{1}$.

Copper chloride with only $\mathrm{KO} t$ - $\mathrm{Bu}$ or with $\mathrm{Ph}_{3} \mathrm{P}$ alone does not promote the hydrostannation. This improved hydrostannation procedure presumably generates the required copper hydride in situ, since $\mathrm{CuCl}, \mathrm{KO} t-\mathrm{Bu}$, and $\mathrm{Ph}_{3} \mathrm{P}$ in the presence of hydrogen or hydrosilane are the starting materials for the preparation of $\mathbf{1}$. In this improved hydrostannation protocol, the addition of hydrosilane is not required as tin hydride serves both as the reductant as well as the stannylating agent. ${ }^{8}$ The reddish brown color of the reaction mixture generated upon mixing of these reagents bears resemblance to the color of $\mathbf{1}$. 
Table 1. Hydrostannation of activated alkynes

130

\begin{tabular}{|c|c|c|c|c|c|c|}
\hline \multirow[t]{2}{*}{ Entry } & \multirow[t]{2}{*}{ Substrate } & \multirow[t]{2}{*}{$\mathrm{R}$} & \multirow[t]{2}{*}{$\mathrm{R}^{\prime}$} & \multicolumn{3}{|c|}{ Conditions $^{\mathrm{a}}$} \\
\hline & & & & A: Yield ${ }^{\mathrm{b}}(3: 4)$ & B: Yield ${ }^{\mathrm{b}}(3: 4)$ & C: Yield (3:4) \\
\hline 1 & $2 \mathbf{a}$ & Et & $\mathrm{OEt}$ & $78 \%(>20: 1)^{\mathrm{c}} ; E$ & $81 \%(>20: 1)^{\mathrm{c}} ; E$ & $92 \%(15: 1)^{\mathrm{e}} ; E$ \\
\hline 2 & 2b & $\mathrm{TBSOCH}_{2}$ & OEt & $74 \%(>20: 1)^{\mathrm{c}} ; E$ & $83 \%^{\mathrm{d}}(>20: 1)^{\mathrm{c}} ; E$ & $84 \%(91: 9)^{\mathrm{f}} ; E$ \\
\hline 3 & $2 c$ & $n-\mathrm{Bu}$ & OEt & $71 \%(>20: 1)^{\mathrm{c}} ; E$ & $75 \%^{\mathrm{d}}(>20: 1)^{\mathrm{c}} ; E$ & $83 \%(3: 1)^{\mathrm{g}}$ \\
\hline 4 & $2 d$ & $n-\mathrm{C}_{6} \mathrm{H}_{13}$ & $\mathrm{OMe}$ & $71 \%(>20: 1)^{\mathrm{c}} ; E$ & $70 \%^{\mathrm{d}}(>20: 1)^{\mathrm{c}} ; E$ & $75 \%(4: 1)^{\mathrm{d}}$ \\
\hline 5 & $2 \mathrm{e}$ & $n-\mathrm{C}_{6} \mathrm{H}_{13}$ & OEt & $78 \%(>20: 1)^{\mathrm{c}} ; E$ & $71 \%(>20: 1)^{\mathrm{c}} ; E$ & \\
\hline 6 & $2 f$ & $n-\mathrm{C}_{6} \mathrm{H}_{13}$ & $\mathrm{O} i-\mathrm{Bu}$ & $79 \%(>20: 1)^{\mathrm{c}} ; E$ & $77 \%^{\mathrm{d}}(>20: 1)^{\mathrm{c}} ; E$ & $83 \%(2: 1)^{\mathrm{d}}$ \\
\hline 7 & $2 \mathrm{~g}$ & $\mathrm{Ph}$ & OEt & $74 \%(>20: 1)^{\mathrm{c}} ; E / Z=3.1: 1^{\mathrm{i}}$ & $65 \%(>20: 1)^{\mathrm{c}} ; E / Z=2.4: 1^{\mathrm{i}}$ & $71 \%(9: 1)^{\mathrm{f}} ; E$ \\
\hline 8 & $2 \mathrm{~h}$ & $\mathrm{Ar}^{\mathrm{h}}$ & $\mathrm{OMe}$ & $73 \%(>20: 1)^{\mathrm{c}} ; E / Z=4.7: 1^{\mathrm{i}}$ & $73 \%(>20: 1)^{\mathrm{c}} ; E / Z=3.8: 1^{\mathrm{i}}$ & $83 \%(2.8: 1)^{\mathrm{j}} ; E$ \\
\hline 9 & $2 \mathbf{i}$ & Et & $\mathrm{Me}$ & $61 \%(>20: 1)^{\mathrm{c}} ; Z$ & $55 \%^{\mathrm{d}}(>20: 1)^{\mathrm{c}} ; Z$ & $58 \% ; Z^{\mathrm{k}}$ \\
\hline 10 & $\mathbf{2 j}$ & $n-\mathrm{C}_{6} \mathrm{H}_{13}$ & $\mathrm{Me}$ & $55 \%(>20: 1)^{\mathrm{c}} ; Z$ & $48 \%^{\mathrm{d}}(>20: 1)^{\mathrm{c}} ; Z$ & $\geq 61 \%$ (not isolated); $E^{\mathrm{g}}$ \\
\hline 11 & $2 \mathrm{k}$ & $n-\mathrm{Bu}$ & $\mathrm{Me}$ & $73 \%(>20: 1)^{\mathrm{c}} ; Z$ & $77 \%(>20: 1)^{\mathrm{c}} ; Z$ & \\
\hline 12 & 2l & $n$-Bu & Et & $68 \%(>20: 1)^{\mathrm{c}} ; E / Z=1: 20^{\mathrm{i}}$ & $69 \%^{\mathrm{d}}(>20: 1)^{\mathrm{c}} \quad E / Z=1: 7.3$ & \\
\hline 13 & $2 \mathrm{~m}$ & $n$-Bu & $t$-Bu & $64 \%(>20: 1)^{\mathrm{c}} ; E / Z=1: 4^{\mathrm{i}}$ & $61 \%^{\mathrm{d}}(>20: 1)^{\mathrm{c}} ; E / Z=1: 4$ & \\
\hline
\end{tabular}

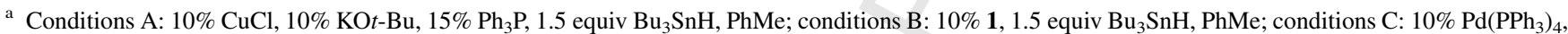
1.5 equiv $\mathrm{Bu}_{3} \mathrm{SnH}$.

b Isolated yields after chromatography.

${ }^{\mathrm{c}}$ Only regioisomer 3 observed by ${ }^{\mathrm{H}} \mathrm{NMR}$ of the crude product mixture.

${ }^{d}$ Ref. 2a.

e Ref. 9a.

${ }^{f}$ Ref. 9 b.

g Ref. 9c.

h $\mathrm{Ar}=5$-benzo[1,3]dioxo-.

${ }^{\mathrm{i}}$ Ratio of $E / Z$ isomers determined from ${ }^{1} \mathrm{H}$ NMR of the crude product mixture.

${ }^{k}$ Ref. $9 \mathrm{e}$.

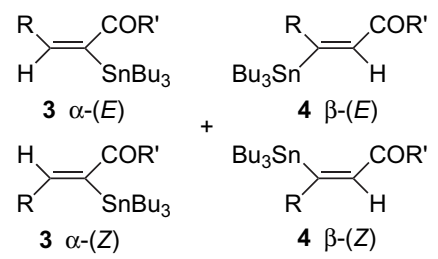

The reaction conditions for hydrostannation were explored for $2 \mathrm{a}$ using $10 \% \mathrm{CuCl}, 10 \% \mathrm{KO}$ - $\mathrm{Bu}$ while varying the amount of $\mathrm{Ph}_{3} \mathrm{P}$ (Table 1). At 10, 15, 20, and $30 \mathrm{~mol} \%$ $\mathrm{Ph}_{3} \mathrm{P}$, the yields of $\mathbf{3 a}$ obtained were $65 \%, 78 \%, 71 \%$, and $52 \%$, respectively, after about $30 \mathrm{~min}$ of reaction. The lower yield at $30 \mathrm{~mol} \% \mathrm{Ph}_{3} \mathrm{P}$ is due to a slower rate of reaction, resulting in incomplete reaction of 2a after $30 \mathrm{~min}$, while conversions were complete at 10,15 , and $20 \mathrm{~mol} \% \mathrm{Ph}_{3} \mathrm{P}$.

Using these optimized conditions, the hydrostannation of various alkynes catalyzed by $10 \% \mathrm{CuCl} / 10 \% \mathrm{KO} t-\mathrm{Bu} / 15 \%$ $\mathrm{Ph}_{3} \mathrm{P}$ (conditions A), by $10 \% \mathrm{I}$ (conditions $\mathrm{B}$ ), and by catalytic palladium (conditions $\mathrm{C}$ ) were compared (Table 1). Notably, the results of the present hydrostannation catalyzed by the in situ generated copper hydride (conditions A) provide vinylstannanes with similar yields and regioselectivities to hydrostannation catalyzed by $\mathbf{1}$ (conditions B). Exclusive $\alpha$-stannation was observed for all acetylenic substrates without exception, showing again similar or superior regioselectivity compared to palladium-catalyzed hydrostannation (conditions $\mathrm{C}$ ), although the latter reaction system is clearly more reactive and the corresponding reaction time is shorter. Under conditions A, some destannylation was observed as a side reaction.

Entries 1-8 (Table 1) show the results of the hydrostannation of acetylenic esters. $\boldsymbol{\alpha}$-Stannation in all cases was exclusive in the copper-catalyzed hydrostannation to give vinylstannanes $\mathbf{3 a}-\mathbf{h}$, and this stands in contrast to the palladium- catalyzed reaction, where $\beta$-stannylated vinylstannanes 4a-h in yields varying from $6-33 \%$ were produced as mixtures with 3a-h.

Aryl-substituted alkynes have not been previously examined in the hydrostannation catalyzed by $\mathbf{1}$ and thus alkynoates $\mathbf{2 g}$ and $\mathbf{2 h}$ are included in the present study. It was found that, while copper-catalyzed hydrostannation of $\mathbf{2 g}$ still generated exclusively $\alpha$-stannated vinylstannane $\mathbf{3 g}$, it was obtained as a 3:1 mixture of syn- and anti-hydrostannated $(E)-\mathbf{3 g}$ and $(Z)$ $\mathbf{3 g}$ (entry 7). Similarly, both $(E)-\mathbf{3 h}$ and $(Z)-\mathbf{3 h}$ were obtained from the reaction of $\mathbf{2 h}$ (entry 8 ). The two modes of addition presumably resulted from initially a syn hydrometallation, followed by an isomerization of the vinyl organometallic via a putative allenoate to the anti-hydrometallated product (Scheme 1). Apparently, in both of the copper-catalyzed hydrostannation reactions, this isomerization is facilitated by aryl groups in conjugation $(\mathrm{R}=\mathrm{Ph}, 5$-benzo[1,3]dioxo-). In the palladium-catalyzed hydrostannation of acetylenic esters, although mixtures arising from non-regioselective stannylation were obtained, isomerization resulting in syn- and anti-hydrometallated products was not observed.

Entries 9-13 (Table 1) show the hydrostannation of acetylenic ketones. Acceptable yields of $\alpha$-stannated vinyl ketones 3 were obtained despite the sensitivity of these compounds to protodestannylation. ${ }^{10}$ For methyl acetylenic ketones $\mathbf{2 i - k}$ $\left(\mathrm{R}^{\prime}=\mathrm{Me}\right)$, both copper and palladium catalyzed-hydrostannation resulted in full isomerization to give exclusively the 
anti-hydrometallated product (Z)-3i-k. Other ketones showed incomplete isomerization, although $(Z)-3$ was the major vinylstannane in all cases. The degree of isomerization appears to be inversely correlated to increasing steric bulk about the ketone (entries 11-13). Comparing the results of the two copper-catalyzed hydrostannations, conditions A tended to result in more isomerization to $(Z)-\mathbf{3}$ than conditions B (entry 12).

\section{Conclusion}

We have described an improved protocol for copper-catalyzed hydrostannation using copper hydride generated in situ from $\mathrm{CuCl}, \mathrm{KO} t$ - $\mathrm{Bu}, \mathrm{Ph}_{3} \mathrm{P}$, and tin hydride reacting as the reductant as well as the stannylating agent. The advantages of this method over the previous hydrostannation catalyzed by Stryker's reagent is that $\mathbf{1}$ does not need to be synthesized separately, and all the precursors could be handled without a dry box, making this an operationally more convenient way to execute the copper-catalyzed hydrostannation, yet delivering the same highly regioselective $\alpha$-stannation products. Under these reaction conditions, alkynoates undergo regioselective syn hydrostannation, except for aryl-substituted alkynoates, which undergo some isomerization to yield both syn and anti hydrostannation products. Alkynones are regioselectively $\alpha$-stannated to yield predominantly the products of anti hydrostannation. This methodology represents a more economical and selective alternative to palladium-catalyzed hydrostannation, especially for larger scale reactions.

\section{Experimental}

\subsection{General}

${ }^{1} \mathrm{H}$ and ${ }^{13} \mathrm{C}$ NMR spectra were recorded in $\mathrm{CDCl}_{3}$ with tetramethylsilane as an internal standard at ambient temperature on a Bruker DPX 300 or Avance 400 FT spectrometer operating at $300 \mathrm{MHz}$ or $400 \mathrm{MHz}$ for ${ }^{1} \mathrm{H}$ and $75 \mathrm{MHz}$ or $100 \mathrm{MHz}$, respectively, for ${ }^{13} \mathrm{C}$. All spectra were calibrated at $\delta 7.26$ or $\delta 0.00 \mathrm{ppm}$ for ${ }^{1} \mathrm{H}$ and $\delta 77.03$ for ${ }^{13} \mathrm{C}$. Both $J$ $\left({ }^{117} \mathrm{SnH}\right)$ and $J\left({ }^{119} \mathrm{SnH}\right)$, and $J\left({ }^{117} \mathrm{SnC}\right)$ and $J\left({ }^{119} \mathrm{SnC}\right)$ values have been reported when the ${ }^{117} \mathrm{Sn}$ and ${ }^{119} \mathrm{Sn}$ satellite peaks are clearly distinct. Otherwise the indicated value of $J_{\mathrm{SnH}}$ and $J_{\mathrm{SnC}}$ must be considered as an approximate mean value of $J\left({ }^{117} \mathrm{SnH}\right)$ and $J\left({ }^{119} \mathrm{SnH}\right)$ due to overlap of the satellite peaks. IR absorption spectra were recorded at solution in $\mathrm{CH}_{2} \mathrm{Cl}_{2}$ on a Bio-Rad FT 165 Spectrophotometer from 4000 to $400 \mathrm{~cm}^{-1}$ with subtraction of peaks for the solvent. Mass spectra were obtained from a Finnigan MAT 95 mass spectrometer for both low resolution and high resolution, with accurate mass reported for the molecular ion $\left(\mathrm{M}^{+}\right)$or the next largest fragment thereof.

Reactions were performed in oven-dried glassware under argon using standard inert atmosphere techniques. Flash column chromatography was performed on E. Merck silica gel 60 (230-400 mesh ASTM). weighed inside a dry box. Tributyltin hydride and methyl 2-butynoate (2a) are used as received. Vinylstannanes $(E)-\mathbf{3 b},{ }^{2 \mathrm{a}}(E)-\mathbf{3 c},{ }^{9 \mathrm{~b}}(E)-\mathbf{3 d},{ }^{9 \mathrm{~b}}(E)-\mathbf{3 f},{ }^{9 \mathrm{~b}}(E)-\mathbf{3 g},{ }^{, \mathrm{b}}(E)-\mathbf{3 h},{ }^{9 \mathrm{~d}}$ (Z)-3h, ${ }^{9 \mathrm{e}}(Z)-\mathbf{3 i},{ }^{9 \mathrm{~b}, \mathrm{e}}(Z)-\mathbf{3 j},{ }^{9 \mathrm{~b}}(Z)-\mathbf{3 l},{ }^{9 \mathrm{~b}}(E)-$, and $(Z)-\mathbf{3 m},{ }^{9 \mathrm{~b}}$ have been previously reported.

\subsection{General procedure for hydrostannation}

$\mathrm{CuCl}(0.10 \mathrm{mmol}), \mathrm{Ph}_{3} \mathrm{P}(0.15 \mathrm{mmol})$, and then $\mathrm{KO} t$-Bu $(0.1 \mathrm{mmol})$ are weighed out into a dry flask, which was then alternately evacuated and refilled with argon three times. The flask is charged with dry, degassed toluene $(2 \mathrm{~mL})$ under argon. The reaction mixture darkens in color upon stirring for $5 \mathrm{~min}$ at room temperature. To this is added $\mathrm{Bu}_{3} \mathrm{SnH}(1.5 \mathrm{mmol})$ with stirring while the reaction mixture takes on a reddish brown color. (This is the characteristic color of active copper hydride reagent; and with inferior quality of $\mathrm{Bu}_{3} \mathrm{SnH}$, this color is not observed, and the consequent hydrostannation is also low yielding.) The alkyne $(1.0 \mathrm{mmol})$ is then added as a solution in dry, degassed toluene $(0.5 \mathrm{~mL})$. The reaction mixture changes to dark brownish black and stirring is continued at room temperature while the reaction is being monitored by TLC. When the substrate has been fully consumed $(\sim 0.5 \mathrm{~h})$, the solvent is removed in vacuo, and the residue is analyzed by ${ }^{1} \mathrm{H}$ NMR spectroscopy to record the ratio of components by integration. Then the crude material is purified quickly by flash chromatography on a short column of $\mathrm{Et}_{3} \mathrm{~N}$-pretreated silica gel to afford the product.

4.2.1. (E)-Ethyl 2-tributylstannylpent-2-enoate (3a). Colorless oil; $R_{f}(5 \%$ EtOAc/Hex $)=0.71 ;{ }^{1} \mathrm{H} \mathrm{NMR}\left(\mathrm{CDCl}_{3}\right.$, $400 \mathrm{MHz}): \delta 6.02\left(\mathrm{t},{ }^{3} J_{\mathrm{HH}}=7.0 \mathrm{~Hz},{ }^{3} J_{\mathrm{SnH}}=62.1 / 59.7 \mathrm{~Hz}\right.$, $1 \mathrm{H}), 4.13(\mathrm{q}, J=7.2 \mathrm{~Hz}, 2 \mathrm{H}), 2.42(\mathrm{dq}, J=7.3,7.2 \mathrm{~Hz}, 2 \mathrm{H})$, $1.50-1.45(\mathrm{~m}, 6 \mathrm{H}), 1.32-1.24(\mathrm{~m}, 9 \mathrm{H}), 1.02(\mathrm{t}, J=7.5 \mathrm{~Hz}$, $3 \mathrm{H}), 0.95-0.91(\mathrm{~m}, 6 \mathrm{H}), 0.87(\mathrm{t}, J=7.2 \mathrm{~Hz}, 9 \mathrm{H}) \mathrm{ppm} ;{ }^{13} \mathrm{C}$ NMR $\left(\mathrm{CDCl}_{3}, 100 \mathrm{MHz}\right): \delta 171.4,154.6\left({ }^{2} J_{\mathrm{SnC}}=11.2 \mathrm{~Hz}\right)$, 134.7, 59.7, $28.7\left({ }^{2} J_{\mathrm{SnC}}=19.8 \mathrm{~Hz}\right), 27.1\left({ }^{3} J_{\mathrm{SnC}}=58.3 \mathrm{~Hz}\right)$, $25.1\left({ }^{3} J_{\mathrm{SnC}}=40.2 \mathrm{~Hz}\right), 14.2,13.6,13.4,10.0\left({ }^{1} J_{\mathrm{SnC}}=345.6 /\right.$ $330.2 \mathrm{~Hz})$ ppm; IR $\left(\mathrm{CH}_{2} \mathrm{Cl}_{2}\right): 2967,2928,2872,2851$, $1698(\mathrm{C}=\mathrm{O}), 1602,1463,1379,1367 \mathrm{~cm}^{-1}$; LRMS (EI, $20 \mathrm{eV}) \mathrm{m} / \mathrm{z}$ (relative intensity): $361\left(\left[\mathrm{M}^{+}-\mathrm{C}_{4} \mathrm{H}_{9}\right], 100\right)$, 317 (65), 315 (53), 261 (21). HRMS (EI) $\mathrm{m} / \mathrm{z}$ calcd for $\mathrm{C}_{15} \mathrm{H}_{29} \mathrm{O}_{2} \mathrm{Sn}\left[\mathrm{M}^{+}-\mathrm{C}_{4} \mathrm{H}_{9}\right]$ : 361.1190, found: 361.1183.

4.2.2. (E)-Ethyl 2-tributylstannylnon-2-enoate (3e). Colorless oil; $R_{f}(10 \% \mathrm{EtOAc} / \mathrm{Hex})=0.69 ;{ }^{1} \mathrm{H} \mathrm{NMR}\left(\mathrm{CDCl}_{3}\right.$, $300 \mathrm{MHz}): \delta 6.04\left(\mathrm{t},{ }^{3} J_{\mathrm{HH}}=7.1 \mathrm{~Hz},{ }^{3} J_{\mathrm{SnH}}=62.3 / 59.9 \mathrm{~Hz}\right.$, $1 \mathrm{H}), 4.14(\mathrm{q}, J=7.1 \mathrm{~Hz}, 2 \mathrm{H}), 2.46-2.38(\mathrm{dt}, J=7.2,7.0 \mathrm{~Hz}$, $2 \mathrm{H}), 1.54-1.43(\mathrm{~m}, 8 \mathrm{H}), 1.34-1.25(\mathrm{~m}, 15 \mathrm{H}), 0.98-0.86$ $(\mathrm{m}, 18 \mathrm{H}) \mathrm{ppm} ;{ }^{13} \mathrm{C} \mathrm{NMR}\left(\mathrm{CDCl}_{3}, 75 \mathrm{MHz}\right): \delta$ 171.6, $154.0\left({ }^{2} J_{\mathrm{SnC}}=11.2 \mathrm{~Hz}\right), 135.9,60.3,32.2\left({ }^{3} J_{\mathrm{SnC}}=39.6 \mathrm{~Hz}\right)$, $32.0,29.6,29.3\left({ }^{2} J_{\mathrm{SnC}}=20.0 \mathrm{~Hz}\right), 27.6\left({ }^{3} J_{\mathrm{SnC}}=57.7 \mathrm{~Hz}\right)$, $22.9,14.8,14.4,14.0,10.6\left({ }^{1} J_{\mathrm{SnC}}=345.1 / 329.8 \mathrm{~Hz}\right) \mathrm{ppm}$; IR $\left(\mathrm{CH}_{2} \mathrm{Cl}_{2}\right): 2961,2929,2872,2855,1694(\mathrm{C}=\mathrm{O}), 1602$, 1465, 1377, 1367, $1348 \mathrm{~cm}^{-1}$; LRMS (EI, $\left.20 \mathrm{eV}\right) \mathrm{m} / z$ (relative intensity): $417\left(\left[\mathrm{M}^{+}-\mathrm{C}_{4} \mathrm{H}_{9}\right], 100\right), 373$ (69), 371 (35), 369 (27). HRMS (EI) $m / z$ calcd for $\mathrm{C}_{19} \mathrm{H}_{37} \mathrm{O}_{2} \mathrm{Sn}$ $\left[\mathrm{M}^{+}-\mathrm{C}_{4} \mathrm{H}_{9}\right]:$ 417.1818, found: 417.1819 .

4.2.3. 3-Phenyl-2-tributylstannylacrylic acid methyl ester (3g). (E)-3g and (Z)-3g were obtained as an inseparable 4.7:1 mixture. (E)-3g: distinguishable peaks: ${ }^{1} \mathrm{H}$ NMR $\left[\left(\mathrm{Ph}_{3} \mathrm{P}\right) \mathrm{CuH}\right]_{6} \quad(\mathbf{1})$ was synthesized, ${ }^{6 \mathrm{~b}}$ then stored, and 
$\left(\mathrm{CDCl}_{3}, 300 \mathrm{MHz}\right): \delta 6.73\left(\mathrm{~s},{ }^{3} J_{\mathrm{SnH}}=59.3 / 58.2 \mathrm{~Hz}, 1 \mathrm{H}\right)$, $4.19(\mathrm{q}, J=7.1 \mathrm{~Hz}, 2 \mathrm{H}), 1.21(\mathrm{t}, J=7.1 \mathrm{~Hz}, 6 \mathrm{H}), 0.93(\mathrm{t}, J=$ $7.3 \mathrm{~Hz}, 9 \mathrm{H}) \mathrm{ppm}$. The characterization corresponded to that reported in the literature. ${ }^{9 \mathrm{~d}}(Z)-\mathbf{3 g}$ : distinguishable peaks: ${ }^{1} \mathrm{H} \mathrm{NMR}\left(\mathrm{CDCl}_{3}, 300 \mathrm{MHz}\right): \delta 8.40\left(\mathrm{~s},{ }^{3} J_{\mathrm{SnH}}=\right.$ $103.3 / 98.9 \mathrm{~Hz}, 1 \mathrm{H}), 7.39-7.22(\mathrm{~m}, 5 \mathrm{H}), 4.27$ (q, J=7.1 Hz, 2H) $\mathrm{ppm}$.

4.2.4. (Z)-3-Tributylstannyloct-3-en-2-one (3k). Colorless oil; $R_{f}=0.6 \quad\left(\mathrm{CH}_{2} \mathrm{Cl}_{2} / \mathrm{Hex}=1: 1\right) ;{ }^{1} \mathrm{H} \quad \mathrm{NMR} \quad\left(\mathrm{CDCl}_{3}\right.$, $300 \mathrm{MHz}): \delta 7.17\left(\mathrm{t},{ }^{3} J_{\mathrm{HH}}=7.3 \mathrm{~Hz},{ }^{3} J_{\mathrm{SnH}}=116.9 / 111.9 \mathrm{~Hz}\right.$, $1 \mathrm{H}), 2.27(\mathrm{~s}, 3 \mathrm{H}), 2.22(\mathrm{dt}, J=7.4,7.2 \mathrm{~Hz}, 2 \mathrm{H}), 1.50-1.26$ $(\mathrm{m}, 16 \mathrm{H}), 0.99-0.85(\mathrm{~m}, 18 \mathrm{H}) \mathrm{ppm} ;{ }^{13} \mathrm{C} \mathrm{NMR}\left(\mathrm{CDCl}_{3}\right.$, $100 \mathrm{MHz}): \delta$ 204.6, 156.5, 148.9, 33.9, 31.3, 28.9 $\left({ }^{2} J_{\mathrm{SnC}}=19.5 \mathrm{~Hz}\right), 27.1 \quad\left({ }^{3} J_{\mathrm{SnC}}=60.8 \mathrm{~Hz}\right), 25.6,22.4,13.8$, 13.5, $11.3\left({ }^{1} J_{\mathrm{SnC}}=345.0 / 329.6 \mathrm{~Hz}\right)$ ppm; IR $\left(\mathrm{CH}_{2} \mathrm{Cl}_{2}\right)$ : 2961, 2922, 2872, 2861, 1669 (C=O), 1618, 1519, 1464, 1368, $1274 \mathrm{~cm}^{-1}$; LRMS (EI, $20 \mathrm{eV}$ ) $\mathrm{m} / z$ (relative intensity): 359 ([ $\left.\left.\mathrm{M}^{+}-\mathrm{C}_{4} \mathrm{H}_{9}\right], 18\right), 293$ (31), 291 (29). HRMS (EI) $\mathrm{m} / \mathrm{z}$ calcd for $\mathrm{C}_{16} \mathrm{H}_{31} \mathrm{OSn}\left[\mathrm{M}^{+}-\mathrm{C}_{4} \mathrm{H}_{9}\right]$ : 359.1397, found: 359.1388 .

\section{Acknowledgements}

We thank Prof. A. Alexakis, University of Geneva, for insightful discussions. The work described in this paper was supported by a grant from the Research grants Council of Hong Kong Special Administrative Region, China (Project No. HKU 7102/02P), and the Areas of Excellence Scheme established under the University Grants Committee of the Hong Kong Special Administrative Region, China (Project No. AoE/P-10/01).

\section{References and notes}

1. (a) Stille, J. K. Angew. Chem., Int. Ed. Engl. 1986, 25, 508; (b) Davies, A. G. Organotin Chemistry; Wiley-VCH: Weinheim, 2004; (c) Pereyre, M.; Quintard, J.-P.; Rahm, A. Tin in Organic Synthesis; Butterworths: London, 1987; (d) Orita, A.; Otera, J. Main Group Metals in Organic Synthesis; Yamamoto, H., Oshima, K., Eds.; Wiley-VCH: Weinheim, 2004; Chapter 12, p 621; (e) Farina, V.; Krishnamurthy, V.;
Scott, W. J. Org. React. 1998, 50, 1; (f) Mitchell, T. N. Synthesis 1992, 803.

2. (a) Leung, L. T.; Leung, S. K.; Chiu, P. Org. Lett. 2005, 7, 5249; (b) Chiu, P.; Leung, L. T. Pure Appl. Chem. 2006, 78, 281.

3. (a) Mahoney, W. S.; Brestensky, D. M.; Stryker, J. M. J. Am. Chem. Soc. 1988, 110, 291; (b) Mahoney, W. S.; Stryker, J. M. J. Am. Chem. Soc. 1989, 111, 8818.

4. Additional reactions that are mediated by $\mathbf{1}$ include reduction of alkynes, hydrosilylation of aldehydes and ketones, reductive Michael, Henry, and aldol reactions: (a) Daeuble, J. F.; McGettigan, C.; Stryker, J. M. Tetrahedron Lett. 1990, 31, 2397; (b) Lipshutz, B. H.; Papa, P. Angew. Chem., Int. Ed. 2002, 41, 4580; (c) Lipshutz, B. H.; Chrisman, W.; Noson, K. J. Organomet. Chem. 2001, 624, 367; (d) Kamenecka, T. M.; Overman, L. E.; Ly Sakata, S. K. Org. Lett. 2002, 4, 79; (e) Chiu, P.; Chung, W. K. Synlett 2005, 55; (f) Chiu, P.; Leung, S. K. Chem. Commun. 2004, 2308; (g) Chiu, P.; Szeto, C. P.; Geng, Z.; Cheng, K. F. Org. Lett. 2001, 3, 1901; (h) de Fátima, Â. Synlett 2005, 1805.

5. (a) Trost, B. M.; Ball, Z. T. Synthesis 2005, 853; (b) Smith, N. D.; Mancuso, J.; Lautens, M. Chem. Rev. 2000, 100, 3257; (d) Rubin, M.; Trofimov, A.; Gevorgyan, V. J. Am. Chem. Soc. 2005, 127, 10243.

6. (a) Brestensky, D. M.; Stryker, J. M. Tetrahedron Lett. 1988, 29, 3749; (b) Chiu, P.; Li, Z.; Fung, C. M. Tetrahedron Lett. 2003, 44, 455; (c) Lee, D.; Yun, J. Tetrahedron Lett. 2005, 46, 2037.

7. Although 1 in the solid state is reported to be able to be handled briefly in air without appreciable decomposition (Ref. 2a,5a), we typically store, handle, and weigh $\mathbf{1}$ in the dry box to protect it from atmospheric humidity.

8. Lipshutz, B. H.; Keith, J.; Papa, P.; Vivian, R. Tetrahedron 1998, 39, 4627.

9. (a) Rossi, R.; Carpita, A.; Cossi, P. Synth. Commun. 1993, 23, 143; (b) Rossi, R.; Carpita, A.; Cossi, P. Tetrahedron 1992, 48, 8801; (c) Zhang, H. X.; Guibe, F.; Balavoine, G. J. Org. Chem. 1990, 55, 1857; (d) Sai, H.; Ogiku, T.; Nishitani, T.; Hiramatsu, H.; Horikawa, H.; Iwasaki, T. Synthesis 1995, 582; (e) Cochran, J. C.; Bronk, B. S.; Terrence, K. M.; Phillips, H. K. Tetrahedron Lett. 1990, 31, 6621.

10. In the palladium-catalyzed hydrostannation, syn-hydrostannylation product $(E)-\mathbf{3 i}$ had been observed to convert to $(Z)-\mathbf{3 i}$ from $-20{ }^{\circ} \mathrm{C}$ to room temperature: Cochran, J. C.; Prindle, V.; Young, H. A.; Kumar, M. H.; Tom, S.; Petraco, N. D. K.; Mohoro, C.; Kelley, B. Synth. React. Inorg. Met.-Org. Chem. 2002, 32, 885 . 